\title{
Risk control analysis of a furniture production activities using hazard identification and risk assessment method
}

\author{
Sri Indrawati, Atyanti Dyah Prabaswari*, and M. Abdul Fitriyanto \\ Industrial Engineering, Universitas Islam Indonesia, Yogyakarta, Indonesia
}

\begin{abstract}
The furniture industry in Indonesia is growing rapidly that leads to technological development. But the use of technology in the industry creates some risk to worker safety. The number of work accidents in Indonesia at the end of 2016 is relatively high. Therefore, this research is conducted to identify hazards and determine risk control using hazard identification and risk assessment method (HIRA). There are three main stages, i.e. identify and analyze hazards, classify hazards and risk control. The result shows that there are nine potential hazards in furniture production, $22 \%$ of it is categorized as high risk level, i.e. hand slashed and fingers cut by machine. Three types of risk control activities are determined to minimize the risk, i.e. administration and engineering control and personal protective equipment.
\end{abstract}

\section{Introduction}

In recent years, the furniture industry in Indonesia is growing rapidly so it gives a big influence to a rapid development of technology. This industry is one of the development priority sector in Indonesia because it is labor-intensive and export-oriented [1]. In fact, the use of technology in industry creates some risk to worker safety. Work accident is one of the factors that must be considered and minimized. Work accidents have three main elements, i.e. unexpected, causing material and nonmaterial losses and disruption of work processes [2]. Some of these conditions are caused by poor worker safety and health management.

The number of work accidents in Indonesia at the end of 2016 is relatively high at 101,367 cases with $2.4 \%$ of deaths [3]. The highest accidents level in the world is wood processing industry that includes furniture industry [4]. Accidents that often occur in the majority industry are caused by human error and dangerous working environment conditions, i.e. manual handling, noise and hazard materials. Most workers are unable to properly identify the workplace potential hazards so that the risk of work becomes greater [5].

In the application of occupational safety and health systems, an industry must have risk management that is hazard identification, risk assessment and occupational risk management [6]. Hazard or the occurrence of things that can harm people, processes, environment around the industry should be well noticed because it is related to the condition of machines, work tools, the nature of work and the production process. Production processes that occur have a great potential hazards, the state of the environment that uses energy is one of the causes of workplace accidents in the work environment. Therefore, an evaluation is required to minimize the potential hazards and risks that occur based on the production process.

Measurement of hazards and risks can be done by choosing the appropriate method with the industry characteristics. An integrated occupational health and safety in plant layout designs is used to minimize hazards from facilities layout design [7]. A hazard identification and risk assessment method (HIRA) is ssuccesfuly used to identify some hazard control in chemistry laboratory [8]. HIRA is used to measure risk level of some potential hazards on the foundry production process [9]. HIRA also used to evaluate potential hazards in paper production. The result show that this method can identify 23 potential hazards with 10 of it categorized as high risks [10].

Hazard identification, risk assessment and determining control (HIRADC) is applied in manufacturing process to prevent accident in workplace [11]. A study is conducted to identify hazards in pharmaceutical manufacturing process using integrated HIRA and failure modes and effect analysis (FMEA) [12]. The integrated method has the ability to reduce the risk and create necessary recommendations to improve worker safety. 10 types of high risk hazard using HIRA method in spare part manufacturing are found [13]. HIRA also used to assess and prioritizing hazards in automotive industry [14]. There are five types of hazards that are identified and a recommendation is to minimize the risk level.

\section{Basic Theory}

An industry should identify all materials, tools and systems of production, to determine the potential hazards [15]. Because this identification is a process that can cause accidents [2]. As well as physical conditions that potentially cause losses such as accidents, equipment

\footnotetext{
* Corresponding author: atyanti.dyah@uii.ac.id
} 
damage, damage to buildings [16]. The level of risk determination of work accidents are often called risk assessment [2]. The risk assessment can measure the likelihood of an activity whether it have a financially detrimental effect, health and safety over a period of time [17].

HIRA is a method for identifying and measuring potential hazard at a workplace that can cause a loss of company or individual. There are three ways to determine the risk, i.e.:

a. Qualitative analysis is a risk analysis method that uses tabulation based on descriptive (high, medium or low).

b. Quantitative analysis is a risk analysis method that uses numeric numbers to express impact and probability.

c. Semi-quantitative analysis, which is a risk analysis method that uses scale numbers for each qualitative category.

Assessment of occupational risks is performed using a scale of 1-5 as shown in Table 1.

Table 1. Risk Probability Level [18]

\begin{tabular}{|l|c|}
\hline \multicolumn{1}{|c|}{ Probability Level } & Description \\
\hline Level 5 (Almost Certain) & $\begin{array}{c}\text { Incidence rate of } 76 \% \text { to } \\
99,99 \%\end{array}$ \\
\hline Level 4 (Likely) & $\begin{array}{c}\text { The probability level is } 60 \% \\
\text { to } 75,99 \%\end{array}$ \\
\hline Level 3 (Possible) & $\begin{array}{c}\text { The probability rate is } 26 \% \\
\text { to } 50,99 \%\end{array}$ \\
\hline Level 2 (Unlikely) & $\begin{array}{c}\text { The probability of } \\
\text { occurrence is } 1 \% \text { to } 25,99 \%\end{array}$ \\
\hline Level 1 (Rare) & $\begin{array}{c}\text { Possible incidence rate up } \\
\text { to } 0,99 \%\end{array}$ \\
\hline
\end{tabular}

Once the risk value is identified, the process of job risk classification can be done using Table 2 .

Table 2. Risk Cathegory [18]

\begin{tabular}{|c|c|l|}
\hline Rank & Level & \multicolumn{1}{|c|}{ Description } \\
\hline $17-25$ & $\begin{array}{c}\text { Extreme High } \\
\text { risk }\end{array}$ & $\begin{array}{l}\text { Unacceptable risks with high } \\
\text { priority mitigation }\end{array}$ \\
\hline $10-16$ & High Risk & $\begin{array}{l}\text { The risk is not acceptable with } \\
\text { medium priority mitigation }\end{array}$ \\
\hline $5-9$ & Medium Risk & $\begin{array}{l}\text { Risks maybe received by } \\
\text { monitoring }\end{array}$ \\
\hline $1-4$ & Low Risk & $\begin{array}{l}\text { Risk maybe accepted without } \\
\text { monitoring }\end{array}$ \\
\hline
\end{tabular}

\section{Research Method}

This research is conducted in an Indonesian furniture industry located in West Java using HIRA method. There are four main stages, i.e. hazard identification, risk assessment, evaluation and risk control. Research begins with observing the work process in the furniture industry. At this stage, the identification of working facilities, work procedures and materials is done. The next stage is to conduct a survey for the identification and confirmation process of the identified hazard. The survey includes the type of hazard that occurs, who is at risk of hazard, when and how long the hazard exposure, the location of the hazard and how hazard exposure occurs. Furthermore, risk evaluation is done by qualitative approach. In-depth analysis is done to determine the priority of each type of hazard. Some hazard control and mitigation measures are developed based on three considerations, i.e. hazard source, exposure mode and exposed workers.

\section{Result and Discussion}

There are eight main production process in furniture industry, i.e. material preparation, cutting raw materials, drying, smoothing, cutting components, sizing and, assembly, finishing and packaging. Each type of process have 2-6 hazards. The highest number of hazards is in cutting components process. While the packaging process only have one type of hazards, i.e. slashed by sharp materials as seen in Appendix 1. There are nine types of hazards based on the identification process that have been done. Once the hazards and risks are identified, then the assessment of the risk of the work is done with the results shown in Table 3.

Table 3. Job Risk Assessment

\begin{tabular}{|c|l|c|c|c|}
\hline No & \multicolumn{1}{|c|}{ Hazards } & $\begin{array}{c}\text { Possible } \\
\text { Weight } \\
\text { Ratio }\end{array}$ & $\begin{array}{c}\text { Weight } \\
\text { Risk }\end{array}$ & $\begin{array}{c}\text { Risk } \\
\text { Value }\end{array}$ \\
\hline 1 & Squashed wood & 2 & 1 & 2 \\
\hline 2 & $\begin{array}{l}\text { Hands slashed } \\
\text { by machine }\end{array}$ & 2 & 3 & 6 \\
\hline 3 & Wood fall & 3 & 4 & 12 \\
\hline 4 & $\begin{array}{l}\text { Eye irritation } \\
\text { and respiratory } \\
\text { disorders }\end{array}$ & 4 & 1 & 4 \\
\hline 5 & $\begin{array}{l}\text { Material } \\
\text { collapse }\end{array}$ & 2 & 2 & 4 \\
\hline 6 & $\begin{array}{l}\text { Finger cut by } \\
\text { sharp material }\end{array}$ & 2 & 3 & 6 \\
\hline 7 & $\begin{array}{l}\text { Kickback of the } \\
\text { wood being cut }\end{array}$ & 3 & 3 & 9 \\
\hline 8 & $\begin{array}{l}\text { Exposure to } \\
\text { paint }\end{array}$ & 4 & 1 & 4 \\
\hline 9 & $\begin{array}{l}\text { Fingers cut off } \\
\text { by machine }\end{array}$ & 3 & 4 & 12 \\
\hline
\end{tabular}

The next stage is risk classification to classified risk based on the total value of hazards. There are two types of hazard included in the category of high risk, i.e. hands slashed by machine and fingers cut of by machine as shown in Table 4.

Then the classification of risk level is converted to get the percentage of risk level as illustrated in Figure 1. Production process in Indonesian furniture industry is dominates with job hazards at low risk level around $45 \%$. $22 \%$ of production process activities are categorized into high risk. Some action plans are developed to lower job hazards especially at high risk level. As a risk control priority that must be done by the industry consist of three types, i.e. administration control, engineering control and personal protective equipment as seen in Table 5. 
Table 4. Risk Classification

\begin{tabular}{|c|c|}
\hline $\begin{array}{l}\text { Risk } \\
\text { Level }\end{array}$ & Hazards \\
\hline Low Risk & $\begin{array}{ll}\text { a. } & \text { Wooden tejepit } \\
\text { b. } & \text { Exposure to powder (eye irritation } \\
\text { and respiratory disorder) } \\
\text { c. Fall of material / at the foot } \\
\text { d. Exposure to paint (eye irritation and } \\
\text { respiratory disorder) }\end{array}$ \\
\hline $\begin{array}{l}\text { Medium } \\
\text { Risk }\end{array}$ & $\begin{array}{l}\text { a. Wood fall } \\
\text { b. Finger cuts sharp objects } \\
\text { c. Kickback from the wood being cut }\end{array}$ \\
\hline High Risk & $\begin{array}{l}\text { a. Hands slashed by machine } \\
\text { b. Fingers cut of by machine }\end{array}$ \\
\hline
\end{tabular}

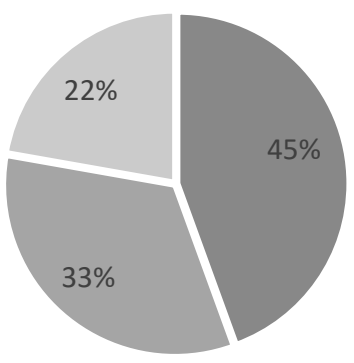

- Low Risk = Medium Risk = High Risk

Fig 1. Risk Presentation Diagram

Table 5. Risk Handling

\begin{tabular}{|c|c|c|}
\hline $\begin{array}{l}\text { Risk } \\
\text { Level }\end{array}$ & Hazards & Risk Control \\
\hline \multirow{3}{*}{$\begin{array}{l}\text { High } \\
\text { Risk }\end{array}$} & \multirow{3}{*}{$\begin{array}{l}\text { Hands } \\
\text { slashed by } \\
\text { machine }\end{array}$} & $\begin{array}{l}\text { 1. Administratiion control: } \\
\text { simplification of work instruction } \\
\text { and stick it to machine. }\end{array}$ \\
\hline & & $\begin{array}{l}2 . \quad \text { Engineering control: } \\
\text { Machine guarding and auxiliary } \\
\text { tool. }\end{array}$ \\
\hline & & $\begin{array}{l}3 . \quad \text { Personal } \\
\text { equipment: gloves }\end{array}$ \\
\hline
\end{tabular}

\section{Conclussion}

Based on the results of research that have been done, it can be concluded that:

a. There are nine job hazards in furniture production process, i.e. pinched fingers, slashed hands and kickback while cutting wood.

b. Job hazards is $22 \%$ at high risk level, $33 \%$ at medium risk level and $45 \%$ at low risk level.

c. Hazards that include high risk level are hands slashed by machine and fingers cut of by machine. Priority risk control plan is simplification and embedding of work instruction in working machines, using gloves, adding machine guarding and thrust tools.
Researchers thank to the support of Industrial Engineering Department, Faculty of Industrial Technology, Universitas Islam Indonesia.

\section{References}

1 Hartarto, A., Kemenperin dan HIMKI Susun Strategi Pacu Kinerja Industri Mebel dan Kerajinan. Indonesian Furniture and Craft Industry Association, https://www.himki-

indonesia.com/post/77/Kemenperin-dan-HIMKISusun-Strategi-Pacu-Kinerja-Industri-Mebel-danKerajinan/id, Accessed on 7 April 2017, (2017)

2 Tarwaka, Managemen dan Implementasi K3 di Tempat Kerja, Harapan Press, Surakarta, (2008)

3 Isafetynews, Kecelakaan Kerja Konstruksi 2017 Diprediksi Tetap Tinggi. http://isafetynews.com/2017/02/01/kecelakaan-kerjakonstruksi-2017-diprediksi-tetap-tinggi/, accessed on 1 Mei 2017, (2017)

4 Vestlund, A.T., Health And Safety In The Furniture Industry, The Furniture Industry Research Association, (2013)

5 Bahn, S. T., Workplace Hazard Identification: What Do People Know And How Is It Done?. Proceedings of Annual Conference of the Association of Industrial Relations Academics Australia and New Zealand. 2012: 1-9. (2012).

6 Suardi, R., Sistem Manajemen Keselamatan dan Kesehatan Kerja, PPM, (2008)

7 Kazerouni, A.M., Chinniah, Y., Agard, B, A Proposed Occupational Health And Safety Risk Estimation Tool For Manufacturing Systems, International Journal of Production Research, Vol. 53. Issue 15: 4459-4475, (2015).

8 Legget, D.J., Lab-HIRA: Hazard Identification And Risk Analysis For The Chemical Research Laboratory: Risk Analysis Of Laboratory Operations, Journal of Chemical Health and Safety, Vol. 19. Issue 5: 25-36, (2012)

9 SheikAllavudeen,S. \& Sankar, S., Hazard Identification, Risk Assessment and Risk Control in Foundry, SSRG International Journal of Industrial Engineering, Volume 2. Issue 3: 1-4, (2015)

10 Sari, R.M., Syahputri, K., Rizkya, I., Siregar, I., Identification of Potential Hazard using Hazard Identification and Risk Assessment, IOP Conf. Series: Materials Science and Engineering, Vol. 180.012120, (2017)

11 Shamsuddin, K.A., Norzaimi, C.M., Che-Ani, A.I., Ismail, A.K., Investigation the effective of the Hazard Identification, Risk Assessment and Determining Control (HIRADC) In Manufacturing Process. International Journal of Innovative Research in Advanced Engineering, Vol.2. Issue 8: 80-84, (2015)

12 Swarnakar, M., Siddiqui, N.A., Baksi, S., Hazard Identification, Risk Analysis And Recommendations For Improving Safety In Pharmaceutical Industry, 
Journal of Management, Information Technology and Engineering, Vol. 2, Issue 2: 23-4, (2016).

13 Restuputri, D.P. \& Fakhri, M., The Analysis Of Health And Safety Aspects By Using Hazard Identification And Risk Assessment (HIRA) Method, Proceeding 8th International Seminar on Industrial Engineering and Management, ER 37-ER44, (2016)

14 Ramesh, R., Prabu, M., Magibalan, S., Senthilkumat, P., Hazard Identification and Risk Assessment in Automotive Industry, International Journal of ChemTech Research, Vol.10. No.4: 352-358, (2017)
15 Department of Occupatinal Safety and Health, Guidelines for Hazard Identification, Risk Assessment and Risk control, Malaysia, (2008)

16 Munawir, A., HAZOP, HAZID, VS JSA, Migas Indonesia, (2010)

17 Kolluru, Rao V., Risk Assesment and Management Handbook for Environmental, Health, and Safety Profesionanals, McGrawhill-Hill, United State Of America, (1996)

18 Global, Risk Management Guidelines, SAI Global. Australia, (2007) 